\title{
Przemoc seksualna wobec osób z niepełnosprawnością intelektualną
}

\begin{abstract}
Karwacka Monika, Sexual violence towards people with intellectual disabilities [Przemoc seksualna wobec osób z niepełnosprawnością intelektualną]. Interdyscyplinarne Konteksty Pedagogiki Specjalnej, nr 2, Poznań 2013. Pp. 57-74. Adam Mickiewicz University Press. ISBN 978-83-232-2594-2. ISSN 2300-391X.

The article discusses the problem of sexual violence towards people with intellectual disabilities. It presents the definition and occurrence of this phenomenon by taking into account the difficulties in estimating the scale of sexual violence towards people with intellectual disabilities. Risk factors for sexual violence that are typical of the general population and people with intellectual disability are analyzed. People with intellectual disabilities are characterized as victims of sexual abuse. This article also deals with the consequences of experiencing sexual violence for the development of people with intellectual disabilities.
\end{abstract}

KEY WORDS: intellectual disability, sexual violence, risk factors, consequences of sexual violence

Zjawisko przemocy seksualnej jest w Polsce od ponad dekady przedmiotem szczególnego zainteresowania praktyków, teoretyków ${ }^{1}$ oraz opinii publicznej. Po okresie zaprzeczania i otaczania

1 Zob. m.in.: M. Beisert, Kazirodztwo. Rodzice w roli sprawców, Wyd. Nauk. Scholar, Warszawa 2004; M. Beisert, Pedofilia - geneza i mechanizm zaburzenia, GWP, Gdańsk 2012; W. Czernikiewicz, B. Pawlak-Jordan, Wykorzystywanie seksualne dzieci, Fundacja Dzieci Niczyje, Warszawa 1988; G. Fluderska, M. Sajkowska, Problem 
tajemnicą tego problemu obserwuje się wzrost zainteresowania, szczególnie w mediach. Medialna przestrzeń wykorzystywana jest zarówno przez wysokonakładowe tabloidy i programy typu talk-show specjalizujące się w sensacyjnym eksponowaniu doświadczeń ofiar przemocy seksualnej, jak i organizacje prowadzące kampanie społeczne o charakterze informacyjno-edukacyjnym, mające na celu wzrost społecznej świadomości i wrażliwości na rzeczywisty wymiar przemocy seksualnej ${ }^{2}$. Stopień oraz dynamika eksponowania problemu przemocy seksualnej w różnego rodzaju publikatorach jest wskaźnikiem polityki medialnej, która kształtuje opinię społeczną, a także jest instrumentem mierzącym znaczenie problemu przemocy seksualnej w życiu publicznym ${ }^{3}$. Uznanie przemocy seksualnej (zwłaszcza wobec dzieci) za społeczny problem zaowocowało interdyscyplinarną wymianą poglądów między ekspertami zajmującymi się problematyką przemocy seksualnej oraz licznymi publikacjami naukowymi i popularnonaukowymi, które dążą do uporządkowania nie tylko kwestii terminologicznych, ale także diagnozy zjawiska - w tym oceny jego skali.

W dostępnych opracowaniach zauważyć można jednak brak empirycznych i teoretycznych rozważań nad przemocą seksualną

krzywdzenia dzieci. Postawy i doświadczenia dorostych Polaków. Raport z badań, Fundacja Dzieci Niczyje, Warszawa 2001; Z. Lew-Starowicz, Przemoc seksualna, Agencja Wydawnicza Jacek Sanatorski \& Co, Warszawa 1992; K. Marzec-Holka, Przemoc seksualna wobec dziecka. Studium pedagogiczno-kryminologiczne, Wyd. Uczelniane WSP w Bydgoszczy, Bydgoszcz 1999; J. Wyżyńska, Jak chronić dzieci przed molestowaniem seksualnym - poradnik nie tylko dla rodziców, Media Rodzina, Poznań 2007.

2 Jednymi z pierwszych kampanii społecznych były m.in.: akcja „Dzieciństwo bez przemocy” z 2001 r. zorganizowana przez Państwową Agencję Rozwiązywania Problemów Alkoholowych oraz Ogólnopolskie Pogotowie dla Ofiar Przemocy w Rodzinie Niebieska Linia, akcja "Zły Dotyk" realizowana w latach 2002-2003 przez telewizję TVN, Niebieską Linię i Fundację Dzieci Niczyje, kampania społeczna „Dziecko w Sieci” Fundacji Dzieci Niczyje oraz kampania „Stop pedofilom” realizowana przez Fundację Kidprotect.

3 Por. M. Sajkowska, Medialny obraz problemu wykorzystywania seksualnego dzieci, [w:] B. Łaciak (red.), Dziecko we wspótczesnej kulturze medialnej, Instytut Spraw Publicznych, Warszawa 2003, s. 96-120. 
wobec dzieci, młodzieży i dorosłych osób z niepełnosprawnością intelektualną. Stan ten po części znajduje swoje uzasadnienie w licznych uprzedzeniach i stereotypach zakorzenionych $\mathrm{w}$ religii, tradycji oraz kulturze powodujących, iż seksualność osób z niepełnosprawnością intelektualną była do niedawna w pedagogice specjalnej paradygmatem ignorowanym ${ }^{4}$. Zjawisko przemocy seksualnej wobec osób z niepełnosprawnością intelektualną otoczone jest więc podwójnym tabu.

\section{Skala problemu}

Pierwsze artykuły omawiające problem przemocy seksualnej wobec osób z niepełnosprawnością zaczęły pojawiać się w latach 80., początkowo w Stanach Zjednoczonych i Kanadzie, a następnie w Wielkiej Brytanii i innych krajach.

Pomimo iż niektórym z badań nad przemocą seksualną wobec osób z niepełnosprawnością intelektualną zarzuca się niedostatki, a nawet błędy metodologiczne, związane z prowadzeniem analiz na próbach niereprezentacyjnych, nieuwzględnianiem prób kontrolnych oraz brakiem wskazań rodzaju i stopnia niepełnosprawności, płci oraz wieku osób badanych, to ujawniają one, że przemoc seksualna wobec osób z niepełnosprawnością intelektualną ma większy wymiar niż przemoc seksualna wobec osób pełnosprawnych.

Rozmiary przemocy seksualnej wobec osób z niepełnosprawnością przedstawione przez National Center for Injury Prevention and Control (USA) są alarmujące - od 25 do 67\% dorosłych osób z niepełnosprawnością intelektualną (w przypadku kobiet $\mathrm{z}$ tej grupy aż od 51 do 79\%) twierdziło, że doświadczyło przemocy seksualnej. Szacuje się, że wśród niepełnosprawnych nastolatków ten rodzaj przemocy dotyka 4-6\% chłopców oraz 24\% dziewcząt ${ }^{5}$. Z analiz

4 Zob. I. Obuchowska, Obecne $i$ nieobecne paradygmaty w pedagogice specjalnej, „Kwartalnik Pedagogiczny” 1987, nr 4, s. 29-33.

${ }^{5}$ A. Staręga, Niepetnosprawni a przemoc seksualna, „Niebieska Linia” 2003, nr 4, s. $6-17$. 
określających częstość występowania przemocy seksualnej wynika, iż w przypadku osób z niepełnosprawnością intelektualną jest ona oceniana na trzy- do dziesięciokrotnie wyższą niż w populacji osób pełnosprawnych, przy czym tylko 20\% wszystkich przepadków przemocy seksualnej zostaje wykrytych ${ }^{6-7}$.

Badania nad zjawiskiem przemocy seksualnej wobec osób z niepełnosprawnością intelektualną często oprócz wskazania rozmiaru przemocy szacują także ryzyko stania się ofiarą nadużyć seksualnych. W USA ryzyko to jest 4,8 razy większe niż u osób pełnosprawnych $^{8}$.

Opierając się na informacjach pochodzących od opiekunów i wychowawców osób z niepełnosprawnością intelektualną oraz jednostkowych publikacjach, można przypuszczać, że przemoc seksualna wobec osób z niepełnosprawnością intelektualną także w Polsce jest częstym zjawiskiem.

Dokładna ocena skali tego zjawiska jest trudna, a może wręcz niemożliwa ze względu na kilka czynników. Po pierwsze, brakuje badań naukowych nad przemocą seksualną wobec osób z niepełnosprawnością intelektualną oraz rzetelnych statystyk instytucji przyjmujących zgłoszenia przypadków przemocy seksualnej i prowadzących dochodzenia w takich sprawach (policja, sąd, instytucje pozarządowe), uwzględniających choćby podstawowe zmienne, takie jak: płeć, wiek, rodzaj i stopień niepełnosprawności. Po drugie, ukryty charakter zjawiska oraz drażliwość problemu powodują, że dane uzyskiwane $\mathrm{z}$ rejestrów wspomnianych instytucji nie pokrywają się z realnym zakresem zjawiska. Zachodni badacze szacują, iż zaledwie 3\% przypadków przemocy seksualnej wobec osób z niepełnosprawnością intelektualną jest ujawnianych ${ }^{9}$.

${ }^{6}$ D. Mejnartowicz, O tym się nie mówi. Problem wykorzystywania seksualnego osób z upośledzeniem umysłowym, „Bardziej Kochani” 1999, nr 3, s. 10-13.

${ }^{7}$ M. Becker, Sexuelle Gewalt gegen Mädchen mit geistiger Behinderung, Edition Schindele, Heidelberg 2001.

8 Tamże.

${ }^{9}$ D. Valenti-Hein, L. Schwartz, za: A. Lechowska, Przemoc seksualna wobec dzieci z niepetnosprawnością intelektualną, „Dziecko Krzywdzone”, 2008, nr 1, s. 120-127. 
Do nieujawniania przestępstw seksualnych wobec osób niepełnosprawnych intelektualnie przyczynia się między innymi obawa rodzin osób niepełnosprawnych przed ujawnianiem zjawiska (zwłaszcza gdy ma ono charakter kazirodczy, sprawca jest dalszym krewnym lub osobą znaną rodzinie), jak również umniejszanie problemu oraz unikanie odpowiedzialności przez sprawujących opiekę nad osobami z niepełnosprawnością intelektualną podejrzewających występowanie przemocy seksualnej. Innymi czynnikami, które nie są bez znaczenia dla utrzymywania się ciemnej liczby przypadków ${ }^{10}$ przemocy seksualnej wobec osób z niepełnosprawnością intelektualną jest ich niski status społeczny, brak poszanowania praw oraz mała wiarygodność. Deprecjacja praw osób z niepełnosprawnością intelektualną oraz jej wartości osobowej wyraża się potocznym myśleniem, że osoba niepełnosprawna intelektualnie nie jest świadoma doznawanej krzywdy, a przemoc seksualna wobec niepełnosprawnych traktowana jest jako dużo mniej poważne przestępstwo niż w przypadku osoby pełnosprawnej ${ }^{11}$. Ponadto, istnieje stereotypowe przekonanie, że nikt nie mógłby pożądać i nikt nie wykorzystałby seksualnie osoby niepełnosprawnej, ponieważ człowiek niepełnosprawny jest aseksualny i nieatrakcyjny. Należy zaznaczyć, że niektórych sprawców przemocy seksualnej osoby z niepełnosprawnością intelektualną mogą szczególnie pociągać ze względu na stygmat niepełnosprawności (zniekształcone ciało ofiary staje się fetyszem). Ponadto charakterystyczny wygląd osób z niepełnosprawnością (młodszy niż wskazywałby wiek chronologiczny) oraz infantylne zachowanie mogą budzić zainteresowanie pedofilów.

Ważną kwestią pozostaje wiarygodność osób z niepełnosprawnością intelektualną, którą ocenia się jeszcze niżej niż pełnospraw-

${ }^{10}$ Ciemna liczba przestępstw to liczba faktycznie popełnionych przestępstw, które nie zostały zgłoszone organom ściągania (policja, prokuratura), w związku z czym nie zostały odnotowane w żadnym rejestrze i statystykach.

11 Por. K. Nowak-Lipińska, O ignorancji sfery erotycznej osób głębiej upośledzonych umystowo, [w:] S. Kawula, H. Machela (red.), Młodzież a wspótczesne dewiacje i patologie społeczne - diagnoza, profilaktyka, resocjalizacja, Wyd. A. Marszałek, Gdańsk-Toruń 1994, s. 101-106. 
nych dzieci - ofiar przemocy seksualnej. Słowom osób z niepełnosprawnością intelektualną nie wierzy się, gdy są one sprzeczne z wypowiedziami osób pełnosprawnych, zwłaszcza mających autorytet i znaczącą pozycję społeczną. Dodatkowo używa się argumentów związanych $\mathrm{z}$ niskim ilorazem inteligencji, niedomogami pamięci, tendencją do fałszowania rzeczywistości oraz konfabulacją. Niska wiarygodność osób z niepełnosprawnością intelektualną ma ogromne znaczenie w przypadku zgłaszania przestępstwa organom ścigania (policja, prokuratura, sąd).

Do wymienionych czynników blokujących zgłaszanie przypadków przemocy seksualnej wobec osób z niepełnosprawnością intelektualną należy także dodać brak systemu instytucji wyspecjalizowanych w diagnozie, wsparciu i terapii niepełnosprawnych intelektualnie ofiar przemocy seksualnej. Osoby mające wiedzę o doświadczeniu przemocy seksualnej przez niepełnosprawnych często wyrażają opinię, że zgłoszenie przestępstwa wiąże się z przewlekłością postępowania sądowego i w żaden sposób nie rozwiązuje problemu radzenia sobie $\mathrm{z}$ traumą przemocy seksualnej przez osoby $\mathrm{z}$ niepełnosprawnością intelektualną.

\section{Definicja zjawiska}

Przemoc seksualna opisywana i definiowana jest przez przedstawicieli wielu nauk, stąd można wyróżnić między innymi definicje o charakterze prawnym, pedagogicznym, psychologicznym czy socjologicznym ${ }^{12}$. Brak definicyjnej spójności potęguje niejednorodna terminologia. Obok pojęcia przemoc seksualna używane są takie określenia, jak: wykorzystanie seksualne, molestowanie seksualne, nadużycie seksualne, niechciane zachowania seksualne, agresja

12 Analizę definicji przemocy seksualnej można odnaleźć między innymi w opracowaniu M. Sajkowskiej, Wykorzystywanie seksualne dzieci. Ustalenia terminologiczne, skala zjawiska, oblicza problemu społecznego, „Dziecko Krzywdzone. Teoria. Badania. Praktyka" 2002, nr 1, s. 5-28. 
seksualna, przestępstwa seksualne, krzywdzenie seksualne, kazirodztwo, pedofilia, zgwałcenie, wiktymizacja seksualna.

Sposób definiowania przemocy seksualnej (wąski - ograniczający się na przykład do ujmowania przemocy seksualnej wyłącznie w kategoriach cielesnego kontaktu z ofiarą czy aktu penetracji lub szeroki - za przemoc seksualną traktujący również doświadczenia bez kontaktu fizycznego, związane między innymi z kontaktem z ekshibicjonistą czy przymuszaniem do tworzenia i oglądania pornografii) będzie wpływał na zróżnicowanie wskaźników rozpowszechnienia zjawiska.

Definicje przemocy seksualnej, stosowane w prawnej oraz pozaprawnej literaturze, kładą najczęściej akcent na następujące kwestie: wiek ofiary przemocy seksualnej, brak zgody ofiary na zachowania seksualne, relacje między ofiarą a sprawcą, rodzaj zachowań seksualnych, intencje sprawcy oraz skutki zachowań seksualnych ${ }^{13}$. Są one zwykle mało użyteczne dla opisywania przemocy seksualnej wobec osób z niepełnosprawnością intelektualną.

\section{Czynniki ryzyka przemocy seksualnej wobec osób z niepełnosprawnością intelektualną}

Znajomość czynników ryzyka przemocy oraz dynamiki przemocy seksualnej są przydatne podczas diagnozy przemocy seksualnej i służą między innymi różnicowaniu przemocy seksualnej od innej, uwiarygodnianiu diagnozy objawów przemocy seksualnej, zwłaszcza w sytuacji, gdy ofiara nie może zrelacjonować swoich doświadczeń (ofiara jest dzieckiem, nie mówi).

Oprócz czynników ryzyka typowych dla populacji ogólnej można wyróżnić czynniki charakterystyczne dla grupy osób z niepełnosprawnością intelektualną ${ }^{14}$. Czynniki te, jak uważam, można

13 Por. M. Beisert, Kazirodztwo..., dz. cyt.; M. Sajkowska, Wykorzystywanie seksualne, dz. cyt., s. 5-28.

14 Z opisem czynników ryzyka przemocy wobec osób pełnosprawnych (dzieci) można zapoznać się w następujących publikacjach: D. Glaser, S. Frosh, Dziecko 
skatalogować w trzech grupach - czynniki związane z cechami ofiary (niepełnosprawność intelektualna i trudności z niej wynikające), doświadczenia socjalizacyjne (wzrastanie w atmosferze przemocy, podporządkowania, braku szacunku, brak działań edukacyjnych) oraz czynniki sytuacyjne (np. instytucjonalne warunki życia) (zob. tab. 1). Należy zwrócić uwagę na fakt, iż żaden pojedynczy czynnik nie stawia osoby w obliczu ryzyka przemocy seksualnej. Istotna jest raczej konstelacja faktorów oraz wzajemne ich oddziaływanie.

Sytuacja, w której osoby $\mathrm{z}$ niepełnosprawnością intelektualną pozostają w relacji zależności wobec osób pełnosprawnych, stanowi czynnik podwyższonego ryzyka wystąpienia przemocy seksualnej. Relacja zależności dotyczy m.in.: zależności kognitywnej, rozumianej jako podległość intelektualna oraz uleganie wpływom autorytetów; zależności psychicznej, która wyraża się faktem, iż osoba niepełnosprawna jest zdana na pomoc osób trzecich (w tym także osób będących sprawcami przemocy seksualnej); zależności fizycznej, która wyraża się potrzebą opieki, czysto fizycznym brakiem siły i bezbronnością ${ }^{15}$.

W literaturze przedmiotu podkreśla się, że jednym z istotniejszych czynników ryzyka przemocy seksualnej w grupie osób z nie-

seksualnie wykorzystywane, Wyd. Lekarskie PZWL, Warszawa 1995; I. Pospiszyl, Przemoc w rodzinie, WSiP, Warszawa 1994; A.C. Salter, Pokonywanie traumy. Jak zrozumieć i leczyć dorosłe ofiary wykorzystywania seksualnego w dzieciństwie, Media Rodzina, Poznań 2003; A.C. Salter, Drapieżcy. Pedofile, gwałciciele i inni przestępcy seksualni. Kim sa, jak dziataja i jak możemy chronić siebie i nasze dzieci, Media Rodzina, Poznań 2005. Czynniki ryzyka przemocy wobec osób niepełnosprawnych intelektualnie wymienione są w następujących pozycjach: J.P. Morano, Sexual Abuse of the Mentally Retarded Patient: Medical and Legal Analysis for the Primary Care Physician, „Primary Care Companion J. Clin Psychiatry" 2001, nr 3, s. 126-135; D. Mejnartowicz, O tym się nie mówi..., dz. cyt., s. 10-13; M. Becker, dz. cyt.; A. Piekarska, Krzywdzenie dziecka z zaburzeniami rozwojowymi. Przegląd zagadnień teoretyczno-badawczych oraz zastosowanie taksonomii krzywdzenia dziecka, „Dziecko Krzywdzone. Teoria. Badania. Praktyka" 2002, nr 2, s. 63-71.

15 Por. C. Noack, H. Schmid, Sexuelle Gewalt gegen Menschen mit geistiger Behinderung - eine verleugnete Realität, [w:] J. Walter (red.), Sexualität und geistige Behinderung, Edition Schindele, Heidelberg 1996. 
Tabela 1. Wybrane czynniki zwiększające ryzyko przemocy seksualnej wobec osób $\mathrm{z}$ niepełnosprawnością intelektualną

\begin{tabular}{|l|l|}
\hline \multirow{5}{*}{ Cechy ofiary } & $\begin{array}{l}\text { ograniczone umiejętności komunikowania się utrudniające we- } \\
\text { zwanie pomocy, } \\
\text { trudności w rozumienia i przestrzeganiu norm społecznych, } \\
\text { osłabiona ocena sytuacji i intencji sprawcy, } \\
\text { niemożność rozpoznania aktów przemocy (branie ich za coś } \\
\text { innego), } \\
\text { niezdolność do unikania lub wycofywania się z sytuacji krzyw- } \\
\text { dzenia, } \\
\text { niezdolność do zidentyfikowania przestępcy. }\end{array}$ \\
\hline $\begin{array}{l}\text { Doświadczenia } \\
\text { socjalizacyjne }\end{array}$ & $\begin{array}{l}\text { nieposzanowanie praw osobistych osoby, } \\
\text { oczekiwanie od osoby posłuszeństwa i uległości, } \\
\text { niski status społeczny, } \\
\text { niska samoocena, } \\
\text { brak siły w związkach z ludźmi, brak pewności siebie i asertyw- } \\
\text { ności, } \\
\text { brak wiedzy o normach społecznych dotyczących prywatności } \\
\text { i granic osobistych. }\end{array}$ \\
\hline $\begin{array}{l}\text { Czynniki } \\
\text { sytuacyjne }\end{array}$ & $\begin{array}{l}\text { prowadzenie odizolowanego trybu życia, } \\
\text { brak możliwości zwierzenia się komuś, } \\
\text { przyjmowanie leków utrudniających samoobronę w sytuacji za- } \\
\text { grożenia. }\end{array}$ \\
\hline
\end{tabular}

Źr ó d ł o: opracowanie własne

pełnosprawnością intelektualną jest brak orientacji w sprawach płciowych ${ }^{16}$. Konsekwencją braku wiedzy jest bezkrytyczne naśladowanie zachowań seksualnych obserwowanych u innych ludzi, w wyniku czego osoby niepełnosprawne nie tylko ośmieszają się

${ }^{16}$ Pogląd ten wyrażają następujący autorzy: D. Mejnartowicz, O tym się nie mówi..., dz. cyt., s. 10-13; K. Nowak-Lipińska, dz. cyt., s. 101-106; M. Kościelska, Czy i jak wspomagać rozwój poczucia tożsamości seksualnej u osób z niepetnosprawnościa intelektualna, [w:] A. Firkowska-Mankiewicz (red.), XXVIII Sympozjum Naukowe - Życie emocjonalne i rodzinne osób z niepetnosprawnościq intelektualna w aspekcie seksualności, Polskie Stowarzyszenie na rzecz Osób z Upośledzeniem Umysłowym, Warszawa 2003; M. Kościelska, Niechciana seksualność. O ludzkich potrzebach osób niepetnosprawnych intelektualnie, Wyd. Jacek Santorski \& Co, Warszawa 2004; J. Vanier, Mężczyzną i niewiasta stworzyt ich do życia w prawdziwej miłości, Wyd. Apostolstwa Miłości, Kraków 1991. 
i przeżywają głębokie upokorzenia, ale mogą być uznane przez sprawcę przemocy jako prowokujące i zachęcające do kontaktów seksualnych. Odmawianie osobom z niepełnosprawnością intelektualną prawa do edukacji seksualnej czy negowanie potrzeb seksualnych powoduje, że są "osoby niepełnosprawne zupełnie bezradne wobec swojej płciowości i niezdolne do przejęcia nad nią kontroli. Rezultat - większa niż przeciętna liczebność kobiet ulegających gwałtom, mężczyzn onanizujących się bez ograniczeń i wykorzystywanych homoseksualnie"17. Między innymi z tego też względu D. Finkelhor ${ }^{18}$ osoby $\mathrm{z}$ niepełnosprawnością intelektualną nazywa ofiarami dostępnymi, dogodnymi i dyskretnymi.

\section{Osoby z niepełnosprawnością intelektualną - ofiary przemocy seksualnej}

Z badań empirycznych oraz wywiadów klinicznych wynika, że wśród ofiar przemocy seksualnej znajdują się zarówno chłopcy, jak i dziewczęta z niepełnosprawnością intelektualną, przy czym, podobnie jak w przypadku osób pełnosprawnych, ofiarami są zdecydowanie częściej dziewczęta ${ }^{19,} 20$.

Ofiary przemocy seksualnej to zarówno dzieci, młodzież, jak i osoby dorosłe. D. Mejnartowicz ${ }^{21}$ podaje, że ze względu na wiek ofiary znajdują się w przedziale od 8. do 45. roku życia. W poradniku dla terapeutów Sexuality and the Mentally Retarded, opracowanym przez R. Kramer, o osobach z lekką niepełnosprawnością intelektualną można przeczytać, że „mają one częste kontakty kazirodcze,

17 M. Kościelska, Czy i jak wspomagać..., dz. cyt., s. 30.

18 D. Finkelhor, za: D. Mejnartowicz, O tym się nie mówi..., dz. cyt., s. 11.

19 Por. H. Sequeira, P. Howlin, Psychological disturbance associated with sexual abuse in people with learning disabilities. Case-control study, "British Journal of Psychiatry" 2003, nr 183, s. 451-456.

20 Por. T. Sobsey, T. Doe, Patterns of sexual abuse and assault, "Sexuality and Disability" 1991, nr 9, 3, s. 243-259.

${ }^{21}$ D. Mejnartowicz, O tym się nie mówi..., dz. cyt., s. 12. 
czasami działając pod przymusem"22. J.P. Morano ${ }^{23}$ sugeruje, że częstszymi ofiarami przemocy seksualnej będą właśnie osoby z lekką niepełnosprawnością intelektualną. Autor pogląd swój wiąże z dużym stopniem samodzielności tej grupy, swobodą osobistą, możliwością nawiązywania licznych kontaktów i relacji z innymi ludźmi oraz z podejmowaną aktywnością seksualną. Jednocześnie badania S. Elvik 24 przeprowadzone na 35 dziewczętach i kobietach w wieku od 13 do 55 lat z głęboką niepełnosprawność intelektualną wykazały, iż u 37\% badanych zauważono zmiany w narządach płciowych jako skutek wcześniejszych i długotrwałych penetracji waginalnych. A. Chamberlein i współpracownicy 25 dowiedli, że 1/3 kobiet z lekką, 1/4 z umiarkowaną oraz 1/10 ze znaczną niepełnosprawnością intelektualną było dotkniętych gwałtami lub stosunkiem kazirodczym. Oznacza to, że ofiarami przemocy seksualnej są oraz na przemoc seksualną mogą być narażone osoby bez względu na zakres i głębokość deficy tów intelektualnych.

Osoby z niepełnosprawnością intelektualną - ofiary przemocy seksualnej spotykają się z wszelkimi formami przemocy seksualnej, a krzywdzące doświadczenia powtarzają się i trwają latami. Badania prowadzone w grupie 54 osób - kobiet i mężczyzn z lekką, umiarkowaną i znaczną niepełnosprawnością intelektualną ujawniły, iż osoby te doświadczały przemocy seksualnej więcej niż jednokrotnie (31\% badanych od 2 do 10 razy, a 33\% powyżej 10 razy). Czas trwania przemocy seksualnej w przypadku 20\% badanych dotyczył kilku miesięcy, a lat aż wobec $44 \%$ ofiar $^{26}$. Ocena sytuacji oraz form przemocy seksualnej we wspomnianym badaniu wykazała, że nastąpiło wiele różnorodnych niechcianych zachowań seksu-

${ }^{22}$ R. Kramer, za: D. Mejnartowicz, Seksualność osób z zespotem Downa, [w:] A. Suchcicki (red.), Wieczne dzieci czy dorośli: problem seksualności osób z niepetnosprawnościq intelektualna, Stowarzyszenie Rodzin i Opiekunów Osób z Zespołem Downa Bardziej Kochani, Warszawa 2002, s. 12.

23 J.P. Morano, dz. cyt., s. 126-135.

24 S. Elvik, za: M. Becker, dz. cyt.

25 A. Chamberlein, za: D. Mejnartowicz, O tym się nie mówi..., s. 10-13.

${ }^{26}$ H. Sequeira, P. Howlin, dz. cyt., s. 451-456. 
alnych wobec osób z niepełnosprawnością intelektualną. Dotyku seksualnego w okolicach piersi, genitaliów, odbytu lub ust doświadczyło 12 spośród 54 osób (22\%), masturbacji 7 osób (13\%), seksu oralnego $5(9 \%)$, a stosunku seksualnego 25 spośród badanych ofiar $(46 \%)^{27}$.

Analiza relacji między ofiarą a sprawcą przemocy seksualnej burzy mit o tym, że przemoc seksualna jest aktem dokonywanym przez osoby obce, nieznane ofierze.

Przemoc seksualna najczęściej jest aktem planowanym i powtarzającym się, jest wynikiem świadomych procesów i starannych działań zachodzący po stronie sprawcy. Sprawca jest najczęściej osobą znaną niepełnosprawnej intelektualnie ofierze. I. Achilles ${ }^{28}$ podaje, że kryminolodzy wychodzą z założenia, że 75\% sprawców przemocy seksualnej wobec osób z niepełnosprawnością intelektualną wywodzi się z bezpośredniego otoczenia ofiar. Inne badania wskazują, że od 97 do 99\% prześladowców jest znanych i darzonych przez osoby z niepełnosprawnością intelektualną zaufaniem ${ }^{29}$.

D. Sobsey i T. Doe ${ }^{30}$ wskazali, że wśród 162 doniesień o przemocy seksualnej wobec osób niepełnosprawnych największy procent sprawców (28\%) stanowili opiekunowie i asystenci oraz lekarze psychiatrzy. Ponadto, 19\% sprawców przemocy seksualnej było członkami rodziny naturalnej lub przyrodniej ofiar, 15,2\% to znajomi (sąsiedzi, przyjaciele rodziny), a 9,8\% opiekunowie nieformalni. Podobną zależność zauważyć można, analizując przywoływane badania H. Sequeira i P. Howlin ${ }^{31}$. Stwierdziły one, iż w $24 \%$ przypadków przemocy seksualnej sprawca był rodzicem, w $13 \%$ - innym członkiem rodziny, w 22\% - opiekunem zawodowo związanym $\mathrm{z}$ ofiarą. W badaniach $\mathrm{N}$. Baladeriana ${ }^{32}$ częściej sprawcami

27 Tamże.

${ }^{28}$ I. Achilles, Was macht Ihr Sohn den, da? Geistige Behinderung und Sexualität, Piper GmbH/Co KG, München 1990.

${ }^{29}$ N. Baladerian, Sexual abuse of people with developmental disabilities, "Sexuality and Disability" 1991, nr 9, 4, s. 323-335; por. A. Staręga, dz. cyt., s. 6-17.

30 T. Sobsey, T. Doe, dz. cyt., s. 243-259.

${ }^{31}$ H. Sequeira, P. Howlin, dz. cyt., s. 451-456.

32 N. Baladerian, dz. cyt., s. 323-335. 
przemocy seksualnej wobec osób z niepełnosprawnością intelektualną byli członkowie personelu opieki społecznej, przewoźnicy lub indywidualni asystenci (44\%), natomiast w 32\% sprawca wywodził się z rodziny ofiary lub spośród znajomych. Sprawcami przemocy seksualnej bywają także osoby z niepełnosprawnością intelektualną - równolatkowie lub osoby nieco starsze i silniejsze od ofiary.

Studia nad miejscem, w którym najczęściej dochodzi do aktów przemocy seksualnej33, wykazały, że w 45\% analizowanych przypadków miejscem rozgrywającego się dramatu było miejsce zamieszkania ofiary - mieszkanie lub sypialnia czy łazienka. Można było o tym wnioskować na podstawie analizy relacji łączących ofiarę i sprawcę przemocy seksualnej. W 31\% zdarzeń związanych z przemocą seksualną dopuszczono się jej w mieszkaniu lub samochodzie sprawcy, a $24 \% \mathrm{w}$ miejscach uznawanych raczej za publiczne, jak na przykład miejsce pracy czy przystanek autobusowy.

Osoby z niepełnosprawnością intelektualną stają się ofiarami przemocy seksualnej także podczas pobytów w szpitalach psychiatrycznych, domach pomocy społecznej lub innych zakładach (internatach, ośrodkach szkolno-wychowawczych). Tam zostają włączone, czasem niezwykle brutalnie, w praktyki homoseksualne, także grupowe ${ }^{34}$. Przemoc seksualna w wymienionych instytucjach bywa konsekwencją lekceważenia sfery prywatnej i intymnej osób z niepełnosprawnością intelektualną przez personel.

Powszechne są sytuacje obnażania się osób z niepełnosprawnością intelektualną i jawnej masturbacji. Osoby poddawane są też publicznym higienicznym i medycznym zabiegom.

S. Tomkiewicz i E. Zucman ${ }^{35}$ wskazują, że personel ośrodków wykorzystuje osoby z niepełnosprawnością intelektualną do zaspokajania własnych pragnień i potrzeb seksualnych. Autorzy podają, że zjawisko to ma tradycyjną formę, to znaczy ukrytą, brutalną, której instytucje zaprzeczają i nie pozwalają, by osoby z zewnątrz dowiedziały się o jej istnieniu i jednocześnie traktują proceder po-

${ }^{3}$ D. Sobsey, C. Varnhagen, za: M. Becker, dz. cyt.

34 Zob. K. Nowak-Lipińska, dz. cyt., s. 101-106 oraz J. Vanier, dz. cyt.

35 S. Tomkiewicz, E. Zucman, za: J. Vanier, dz. cyt. 
błażliwie. Inna forma przemocy seksualnej w instytucjach, to, jak nazwali ją autorzy, przemoc nowoczesna lub gwałt zinstytucjonalizowany. Personel, dążąc do zaspokojenia własnych popędów, prowokuje osoby z niepełnosprawnością intelektualną do wyrażania seksualnych pragnień, które zostają przez pracowników spełniane i tłumaczone jako działania terapeutyczne. Na fakt nadużyć seksualnych wobec osób z niepełnosprawnością intelektualną przez nauczycieli i pseudoterapeutów zwraca uwagę M. Kościelska ${ }^{36}$. Podkreśla, że dochodzi do nich ze względu na zaburzenia seksualne u osób sprawujących opiekę.

Odnotowane przypadki przemocy seksualnej wobec osób z niepełnosprawnością intelektualną dokonywane przez osoby zawodowo związane z pomocą pedagogiczną i psychosocjalną potwierdzają spostrzeżenia A.C. Salter ${ }^{37}$, że sprawcy, dążąc do bliskiego emocjonalnego i fizycznego kontaktu z ofiarą, wykorzystują swój zawód lub hobby.

\section{Konsekwencje doświadczanej przemocy seksualnej przez osoby z niepełnosprawnością intelektualną}

Z badań o charakterze klinicznym i empirycznym wynika, iż trauma przemocy seksualnej zaburza naturalny przebieg rozwoju i funkcjonowania ofiary w wielu sferach. Konsekwencje doświadczanej przemocy manifestują się nie tylko $\mathrm{w}$ sferze seksualności ofiary, ale również jej: zdrowia fizycznego, stanu emocjonalnego, rozwoju umysłowego i społecznego ${ }^{38}$.

${ }^{36}$ M. Kościelska, Niechciana seksualność..., dz. cyt., s. 55.

37 A.C. Salter, Pokonywanie traumy..., dz. cyt.; A.C. Salter, Drapieżcy..., dz. cyt.

38 Zob. Z. Lew-Starowicz, dz. cyt.; A. Widera-Wysoczańska, Proces zdrowienia osób, które doznaty urazu w dzieciństwie, [w:] L. Gapik (red.), Postępy psychoterapii. Wybrane zagadnienia teoretyczne, Wyd. Interfund, Poznań 1999, s. 102-112, M. Zielona-Jenek, Wykorzystanie seksualne - trauma nadużycia czy trauma ujawnienia?, [w:] A. Brzezińska, S. Jabłoński, M. Marchow (red.), Ukryte piętno. Zagrożenia rozwoju w okresie dzieciństwa, Wyd. Fundacji Humaniora, Poznań 2003, s. 223-243. 
Tabela 2. Konsekwencje przemocy seksualnej

\begin{tabular}{|c|c|c|}
\hline \multirow{2}{*}{ Sfera } & \multicolumn{2}{|c|}{ Konsekwencje } \\
\hline & krótkoterminowe & długoterminowe \\
\hline $\begin{array}{l}\text { Sfera so- } \\
\text { matyczna }\end{array}$ & $\begin{array}{l}\text { urazy pochwy i błony dziewiczej, } \\
\text { obecność spermy, urazy żołędzi, } \\
\text { trzonu prącia lub worka mosz- } \\
\text { nowego. }\end{array}$ & $\begin{array}{l}\text { zaburzenia miesiączkowania, } \\
\text { bezsenność, zaburzenia jedzenia. }\end{array}$ \\
\hline $\begin{array}{l}\text { Sfera emo- } \\
\text { cjonalna }\end{array}$ & $\begin{array}{l}\text { lęki, obniżenie nastroju, smutek, } \\
\text { przygnębienie drażliwość, złość } \\
\text { wstyd, poczucie winy, krzywdy, } \\
\text { obniżenie poczucia własnej war- } \\
\text { tości, zaburzenia snu. }\end{array}$ & $\begin{array}{l}\text { zespół stresu pourazowego, lęk, } \\
\text { depresja, zachowania autode- } \\
\text { strukcyjne (próby samobójcze, } \\
\text { uszkodzenia ciała), negatywna } \\
\text { samoocena, labilność emocjo- } \\
\text { nalna. }\end{array}$ \\
\hline $\begin{array}{l}\text { Sfera sek- } \\
\text { sualna }\end{array}$ & $\begin{array}{l}\text { znajomość zachowań seksualnych } \\
\text { nieadekwatna do fazy rozwoju } \\
\text { psychoseksualnego, wczesna, nad- } \\
\text { mierna, nieadekwatna do fazy roz- } \\
\text { woju psychoseksualnego mastur- } \\
\text { bacja, pobudzenie seksualne. }\end{array}$ & $\begin{array}{l}\text { negatywne postawy wobec seksu, } \\
\text { fobie seksualne, zaburzenia iden- } \\
\text { tyfikacji z rolą płciową, skłonność } \\
\text { do seksualnego wykorzystywania } \\
\text { innych. }\end{array}$ \\
\hline $\begin{array}{l}\text { Sfera po- } \\
\text { znawcza } \\
\text { i społeczna }\end{array}$ & $\begin{array}{l}\text { trudności w koncentracji uwagi, } \\
\text { niepowodzenia w nauce, ucieczki } \\
\text { z domu, izolowanie się. }\end{array}$ & $\begin{array}{l}\text { uzależnienia (narkomania, alko- } \\
\text { holizm), zachowania przestępcze. }\end{array}$ \\
\hline
\end{tabular}

Ź r ó d ł o: opracowanie własne

Kierując się kryterium czasu wystąpienia konsekwencji doznanej przemocy seksualnej, dzieli się je na krótko- i długoterminowe (zob. tab. 2). Krótkoterminowe konsekwencje pojawiają się w okresie do dwóch lat od momentu ustania krzywdzenia. Natomiast za długoterminowe konsekwencje przemocy seksualnej uznaje się takie następstwa, które utrzymują się bądź pojawiają po upływie dwóch lat od aktów przemocy.

Niegdyś dość powszechny był pogląd, iż skutki przemocy seksualnej wobec osób z niepełnosprawnością intelektualną nie są tak traumatyczne, jak w przypadku osób zdrowych i sprawnych z uwagi na ich ograniczoną percepcję, rozumienie i ocenę zdarzeń ${ }^{39}$. Obecnie

39 A. Piekarska, dz. cyt., s. 65. 
uważa się, że skutki przemocy seksualnej u osób z niepełnosprawnością są podobne i nie różnią się w zasadniczy sposób od reakcji osób pełnosprawnych ${ }^{40}$. Należy jednak pamiętać, że zdiagnozowanie symptomów przemocy seksualnej w tej grupie jest utrudnione między innymi ze względu na ograniczenia w komunikacji - trudności w mówieniu, brak mowy, ograniczenia związane z wyrażaniem myśli i odczuć.

Znajomość wymienionych $\mathrm{w}$ tabeli 2 podstawowych symptomów seksualnego nadużycia niewątpliwie może przyczynić się do wykrycia przemocy seksualnej i bezzwłocznego udzielenia ofierze pomocy terapeutycznej. Istnieje niebezpieczeństwo, że niektóre z symptomów w przypadku osób z niepełnosprawnością intelektualną (np.: masturbacja, zachowania stereotypowe, autoagresja, lepkość emocjonalna, depresja, apatia) mogą być interpretowane jako wynik zaburzeń funkcji poznawczych per se lub innych zdarzeń życiowych. Wskazana sytuacja utrudni udzielenie skutecznej pomocy ofierze; może także prowadzić do eskalacji zachowań trudnych.

W dokumencie ONZ dotyczącym Standardowych Zasadach Wyrównywania Szans Osób Niepełnosprawnych zapisano: „Osoby niepełnosprawne i ich rodziny powinny być w pełni informowane o środkach ostrożności zapobiegających nadużyciom seksualnym lub innym formom nadużyć. Osoby niepełnosprawne są szczególnie narażone na nadużycia w rodzinie, środowisku lub zakładzie i trzeba je nauczyć, jak unikać takich okoliczności, jak rozpoznać czy nadużycie miało miejsce oraz jak je zgłosić (zasada 9, punkt 4)".

To istotne zadanie pedagogiki specjalnej oraz systemu edukacji osób z niepełnosprawnością intelektualną będzie mogło być w pełni zrealizowane, gdy przemoc seksualna wobec osób z niepełnosprawnością intelektualną uznana zostanie za problemem społeczny. Konieczne jest zrozumienia, że ukrywanie przemocy daje poczucie bezkarności sprawcy i zaprzecza krzywdzie osób z niepełnosprawnością intelektualną.

${ }^{40}$ H. Sequeira, P. Howlin, dz. cyt., s. 451-456. 


\section{Bibliografia}

ACHILlES I., Was macht Ihr Sohn den, da? Geistige Behinderung und Sexualität, Piper GmbH/Co KG, München 1990.

BALADERIAN N., Sexual abuse of people with developmental disabilities, "Sexuality and Disability" 1991, nr 9, 4, s. 323-335.

BECKER M., Sexuelle Gewalt gegen Mädchen mit geistiger Behinderung, Edition Schindele, Heidelberg 2001.

BEISERT M., Kazirodztwo. Rodzice w roli sprawców, Wyd. Nauk. Scholar, Warszawa 2004.

BEISERT M., Pedofilia - geneza i mechanizm zaburzenia, GWP, Gdańsk 2012.

CZERNIKIEWICZ W., PAWLAK-JORDAN B., Wykorzystywanie seksualne dzieci, Fundacja Dzieci Niczyje, Warszawa 1988.

FLUDERSKA G., SAJKOWSKA M., Problem krzywdzenia dzieci. Postawy $i$ doświadczenia dorostych Polaków. Raport z badań, Fundacja Dzieci Niczyje, Warszawa 2001.

GLASER D., Frosh S., Dziecko seksualnie wykorzystywane, Wyd. Lekarskie PZWL, Warszawa 1995.

KoścIELSKA M., Czy i jak wspomagać rozwój poczucia tożsamości seksualnej u osób z niepetnosprawnością intelektualna, [w:] A. Firkowska-Mankiewicz (red.), XXVIII Sympozjum Naukowe - Życie emocjonalne i rodzinne osób z niepetnosprawnością intelektualna w aspekcie seksualności, Polskie Stowarzyszenie na rzecz Osób z Upośledzeniem Umysłowym, Warszawa 2003.

KOŚCIELSKA M., Niechciana seksualność. O ludzkich potrzebach osób niepetnosprawnych intelektualnie, Wyd. Jacek Santorski \& Co, Warszawa 2004.

LECHOWSKA A., Przemoc seksualna wobec dzieci z niepetnosprawnościa intelektualna, „Dziecko Krzywdzone”, 2008, nr 1, s. 120-127.

LeW-Starowicz Z., Przemoc seksualna, Agencja Wydawnicza Jacek Sanatorski \& Co, Warszawa 1992.

MARZEC-HOLKA K. Przemoc seksualna wobec dziecka. Studium pedagogiczno-kryminologiczne, Wyd. Uczelniane WSP w Bydgoszczy, Bydgoszcz 1999.

Mejnartowicz D., O tym się nie mówi. Problem wykorzystywania seksualnego osób z upośledzeniem umysłowym, „Bardziej Kochani” 1999; nr 3, s. 10-13.

MejnarTowicz D., Seksualność osób z zespołem Downa, [w:] A. Suchcicki (red.), Wieczne dzieci czy dorośli: problem seksualności osób z niepetnosprawnościa intelektualna, Stowarzyszenie Rodzin i Opiekunów Osób z Zespołem Downa Bardziej Kochani, Warszawa 2002, s. 5-28.

MorANO J.P., Sexual Abuse of the Mentally Retarded Patient: Medical and Legal Analysis for the Primary Care Physician, "Primary Care Companion J. Clin. Psychiatry” 2001, 3, s. 126-135.

NOACK C., SCHMID H., Sexuelle Gewalt gegen Menschen mit geistiger Behinderung - eine verleugnete Realität, [w:] J. Walter (red.), Sexualität und geistige Behinderung, Edition Schindele, Heidelberg 1996. 
NOWAK-LIPIŃSKA K., O ignorancji sfery erotycznej osób głębiej upośledzonych umystowo, [w:] S. Kawula, H. Machela (red.), Młodzież a wspótczesne dewiacje i patologie spoteczne - diagnoza, profilaktyka, resocjalizacja, Wyd. A. Marszałek, Gdańsk-Toruń 1994, s. 101-106.

OBUCHOWSKA I., Obecne i nieobecne paradygmaty w pedagogice specjalnej, „Kwartalnik Pedagogiczny" 1987, nr 4, s. 29-33.

PIEKARSKA A., Krzywdzenie dziecka z zaburzeniami rozwojowymi. Przeglad zagadnień teoretyczno-badawczych oraz zastosowanie taksonomii krzywdzenia dziecka, „Dziecko Krzywdzone. Teoria. Badania. Praktyka" 2002, nr 2, s. 63-71.

POSPISZYL I., Przemoc $w$ rodzinie, WSiP, Warszawa 1994.

SAJKOWSKA M., Medialny obraz problemu wykorzystywania seksualnego dzieci, [w:] B. Łaciak (red.), Dziecko we wspótczesnej kulturze medialnej, Instytut Spraw Publicznych, Warszawa 2003, s. 96-120.

SAJKOWSKA M., Wykorzystywanie seksualne dzieci. Ustalenia terminologiczne, skala zjawiska, oblicza problemu społecznego, „Dziecko Krzywdzone. Teoria. Badania. Praktyka" 2002, nr 1, s. 5-28.

SALTER A.C., Drapieżcy. Pedofile, gwałciciele i inni przestępcy seksualni. Kim sa, jak dziataja i jak możemy chronić siebie i nasze dzieci, Media Rodzina, Poznań 2005.

SALTER A.C., Pokonywanie traumy. Jak zrozumieć i leczyć doroste ofiary wykorzystywania seksualnego w dzieciństwie, Media Rodzina, Poznań 2003.

SEQUEIRA H., HOWLIN P., Psychological disturbance associated with sexual abuse in people with learning disabilities. Case-control study, "British Journal of Psychiatry” 2003, nr 183, s. 451-456.

SOBSEY T., DOE T., Patterns of sexual abuse and assault, "Sexuality and Disability” 1991, nr 9, 3, s. 243-259.

STARĘGA A., Niepetnosprawni a przemoc seksualna, „Niebieska Linia” 2003, nr 4, s. 6-17.

VANIER J., Mężczyzna i niewiasta stworzyt ich do życia w prawdziwej mitości, Wyd. Apostolstwa Miłości, Kraków 1991.

WIDERA-WYSOCZAŃSKA A., Proces zdrowienia osób, które doznaty urazu w dzieciństwie, [w:] L. Gapik (red.), Postępy psychoterapii. Wybrane zagadnienia teoretyczne, Wyd. Interfund, Poznań 1999, s. 102-112.

WYŻYŃSKA J., Jak chronić dzieci przed molestowaniem seksualnym - poradnik nie tylko dla rodziców, Media Rodzina, Poznań 2007.

ZIELONA-JENEK M., Wykorzystanie seksualne - trauma nadużycia czy trauma ujawnienia?, [w:] A. Brzezińska, S. Jabłoński, M. Marchow (red.), Ukryte piętno. Zagrożenia rozwoju w okresie dzieciństwa, Wyd. Fundacji Humaniora, Poznań 2003, s. 223-243. 